\title{
Fluctuations of serum bile acid concentrations during the menstrual cycle
}

\author{
CR PENNINGTON, PE ROSS, J MURISON, AND IAN AD BOUCHIER \\ From the Department of Medicine, Ninewells Hospital and Medical School, Dundee DDI 9SY, UK
}

SUMMARY Fasting primary bile acid conjugates were measured in 44 women by radioimmunoassay methods. Bile acid values were significantly greater in the 21 women who were in the first half of the menstrual cycle than in the 23 women in whom blood was sampled during the second half of the cycle. Similar measurements were made at weekly intervals after menstruation in five subjects; increased values were observed in the first week. It is concluded that serum bile acid values fluctuate during the menstrual cycle.

The measurement of serum bile acids has been advocated for the detection of liver disease. ${ }^{1-3}$ Few studies have reported fasting serum bile acid values in small numbers of normal subjects. ${ }^{45}$ So far the influence of factors such as age, drug therapy, and the menstrual cycle on fasting serum bile acids has remained largely unknown.

Serum and biliary lipid composition is known to change during the course of the menstrual cycle. ${ }^{6}$ We describe changes in the serum bile acid values which were observed during the menstrual cycle.

\section{Methods}

Fasting blood samples were obtained from 44 healthy women, who were receiving no drug or oral contraceptive therapy, and in whom conventional biochemical liver function tests and serum lipid values were normal. They were assigned to one of two groups according to the phase of the menstrual cycle which was determined on historical grounds. Blood samples were obtained from a further five subjects at weekly intervals from the onset of the menstrual cycle.

Serum was stored at $-20^{\circ} \mathrm{C}$ until analysed for primary bile acid conjugation by a radioimmunoassay method. ${ }^{7}$ Student's $t$ test was used to compare serum bile acid values in each phase of the menstrual cycle.

\section{Results}

In the first half of the menstrual cycle 21 women ( $31 \pm 8$ years) were sampled, and in the second half

Accepted for publication 9 July 1980

\begin{tabular}{|c|c|c|c|c|}
\hline \multirow{2}{*}{$\begin{array}{l}\text { Bile acid } \\
(\mu \mathrm{mol} / \mathrm{l})\end{array}$} & \multicolumn{4}{|c|}{ Time (weeks after the onset of menstruation) } \\
\hline & 0 & 1 & 2 & 3 \\
\hline Cholate & $\begin{array}{r}0.52 \\
\pm 0.17\end{array}$ & $\begin{array}{c}0.72^{*} \\
\pm 0.25\end{array}$ & $\begin{array}{r}0.60 \\
\pm 0.23\end{array}$ & $\begin{array}{r}0.60 \\
\pm 0.21\end{array}$ \\
\hline Chenodeoxycholate & $\begin{array}{r}0.97 \\
\pm 0.63\end{array}$ & $\begin{aligned} & 1.48 \\
\pm & 1.0\end{aligned}$ & $\begin{array}{r}1.32 \\
\pm 0.65\end{array}$ & $\begin{array}{r}0.98 \\
\pm 0.73\end{array}$ \\
\hline
\end{tabular}

${ }^{*} \mathrm{P}<0.05$

23 subjects ( $30 \pm 8$ years). The cholic acid values in the patients who were in the first half of the menstrual cycle $(0.67 \pm 0.37 \mu \mathrm{mol} / \mathrm{l})$ were significantly greater $(P<0.01)$ than the values obtained in the second half of the cycle $(0.43 \pm 0.17 \mu \mathrm{mol} / \mathrm{l})$. Similarly, chenodeoxycholic acid values obtained in patients who were in the first half of the cycle $(1.4 \pm 1.0 \mu \mathrm{mol} / \mathrm{l})$ exceeded $(\mathrm{P}<0.005)$ values from patients who were in the second half of the cycle $(0.7 \pm 0.4 \mu \mathrm{mol} / \mathrm{l})$.

The bile acid results measured at weekly intervals in five subjects are shown in the Table. Increased values were observed in the first week after the onset of menstruation.

\section{Discussion}

This study has demonstrated a fluctuation of serum bile acid values during the menstrual cycle. Higher levels were observed for both primary bile acid conjugates during the first half of the cycle. The effect of the menstrual cycle should be considered in future studies of factors that influence serum bile acids. In spite of the fact that mean values for 
chenodeoxycholate conjugates obtained in the first half of the cycle were twice those seen in the second phase, total values remained low, and this variation appears unimportant in relation to the use of bile acid measurements for the detection of liver disease. This study offers no explanation for the observed bile acid fluctuations, although it is known that oestrogens, in particular, cause a reduction in the hepatic excretory function. ${ }^{8}$ In any future study it would be of interest to compare bile acid values with the changes in oestrogen and progesterone levels during the course of the menstrual cycle.

We thank Miss Janavicius for typing the manuscript. Financial support was given by the Scottish Hospital Endowments Research Trust.

\section{References}

${ }^{1}$ Barnes S, Gallo GA, Trash DB, Morris JS. Diagnostic value of serum bile acid estimation in liver disease. $J$ Clin Pathol 1975;28:506-9.
${ }^{2}$ Fausa $O$, Gzone E. Serum bile acid concentrations in patients with liver disease. Scand J Gastroenterol 1976; $11: 537-43$.

3 Pennington CR, Ross PE, Bouchier Ian AD. Serum bile acids in the diagnosis of hepatobiliary disease. Gut 1977;18:903-8.

${ }^{4}$ Fausa O, Gzone E. Serum bile acid concentration after a test meal. Scand J Gastroenterol 1976;11:229-32.

5 Pennington CR, Ross PE, Bouchier Ian AD. Fasting and post-prandial serum bile acid concentrations in normal persons using an improved GLC method. Digestion 1978;17:56-62.

${ }^{6}$ Low-Beer TS, Wicks ACB, Heaton, KW, Durrington P, Yeats J. Fluctuations of serum and bile lipid concentrations during the menstrual cycle. $B r$ Med J 1977;1 : 1568-70.

${ }^{7}$ Baqir YA, Murison J, Ross PE, Bouchier Ian AD. Radioimmunoassay of primary bile salts in serum. $J$ Clin Pathol 1979;32:560-4.

${ }^{8}$ Simmon FR. Effects of oestrogens on the liver. Gastroenterology $1978 ; 75: 512-4$.

Requests for reprints to: Dr CR Pennington, Department of Medicine, Ninewells Hospital and Medical School, Dundee DD1 9SY. 